\title{
SPATIAL AND TEMPORAL VARIATIONS OF SNOW CHEMISTRY IN TERRE ADÉLIE (EAST ANTARCTICA)
}

\author{
by
}

Michel Legrand and Robert J. Delmas

(Laboratoire de Glaciologie et Géophysique de l'Environnement du C.N.R.S., B.P. 96, 38402 St.-Martin-d'Hères Cedex, France)

\section{ABSTRACT}

The chemistry of recently deposited snow sampled in 1982-83 along a $430 \mathrm{~km}$ coast-interior traverse in Terre Adélie, East Antarctica, is reported. In addition, three firn samples, covering the same time period (1959 to 1969) and collected on the traverse at D 55, D 80 and Dome C stations, respectively at 200,430 and $1070 \mathrm{~km}$ from the sea, are also studied. Concentrations of major soluble impurities $\left(\mathrm{H}^{+}, \mathrm{NH}_{4}^{+}, \mathrm{Na}^{+}, \mathrm{K}^{+}, \mathrm{Cl}^{-}, \mathrm{NO}_{3}^{-}\right.$and $\left.\mathrm{SO}_{4}^{2-}\right)$ were determined by ion chromatography (except $\mathrm{H}^{+}$which was titrated) on more than 200 samples. Conditions of sampling and analysis were carefully controlled in order to avoid contamination problems. A balanced ionic budget was generally obtained for each of the samples. For stations occupying an intermediary position between the coastal areas and the central Antarctic plateau, our results demonstrate that the two major impurities are $\mathrm{H}_{2} \mathrm{SO}_{4}$ and $\mathrm{HNO}_{3}$. $\mathrm{HCl}$ is also present, but at a lower level of concentration; the sea-salt contribution is dominant only at the most coastal sites (within $40 \mathrm{~km}$ ) of the sea. The degree of neutralization of the snow acidity by $\mathrm{NH}_{3}$ is always very low as indicated by the values of $\mathrm{NH}_{4}^{+}$content. The mean concentrations of $\mathrm{H}_{2} \mathrm{SO}_{4}$ along the traverse are relatively constant whereas an increase of the $\mathrm{HNO}_{3}$ concentrations is observed when going

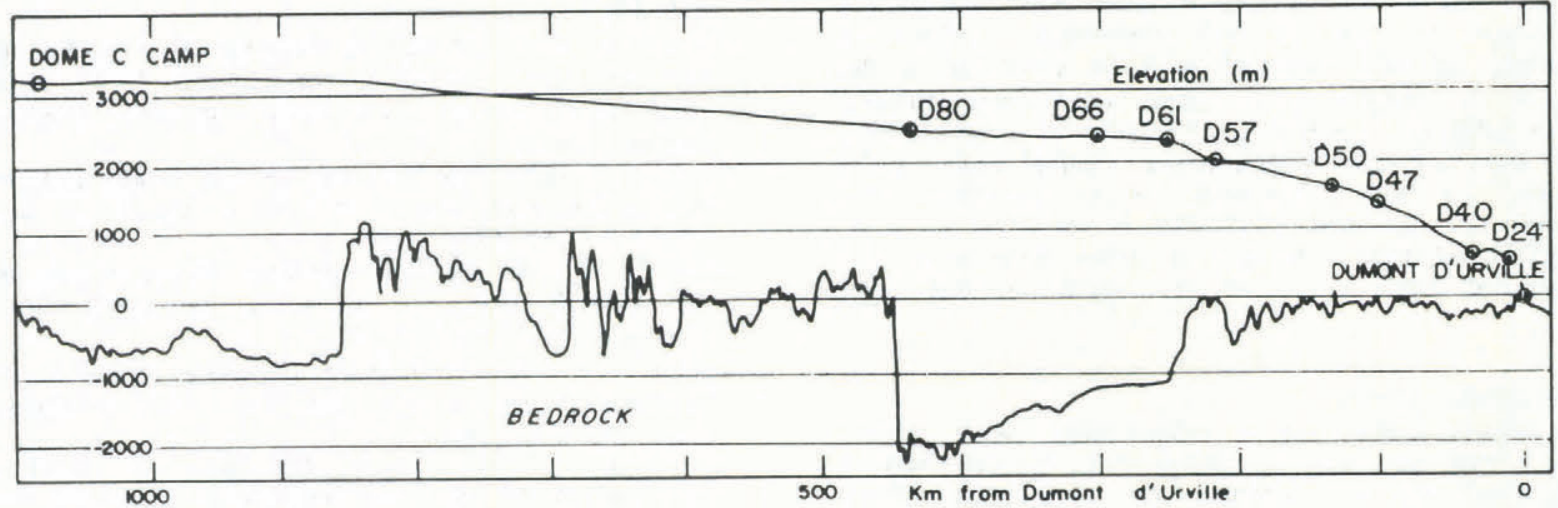

Fig.1. Cross-section of the Antarctic ice sheet in the region of Terre Adélie. The positions of the study sites are indicated.

TABLE I. IONIC CONCENTRATIONS (in $\mu$ eq $1^{-1}$ ) IN SURFACE SNOW AT ALL STUDY STATIONS IN TERRE ADÉLIE (at D80 (1) and (2) correspond to two different samplings. $\sum$ is the sum of ionic concentrations, $\mathrm{C}$ the imbalance of the ion budget $((+)$ indicates an excess of cations vs anions), $\mathrm{SO}_{4}^{2-}$ ex and $\mathrm{Cl}^{-}$ex are excess sulphate and chloride respectively. $" \mathrm{H}^{+}$calculated" (last column) is the sum $\left[\mathrm{SO}_{4}^{2-}\right.$ ex $]+\left[\mathrm{NO}_{3}^{-}\right]+\left[\mathrm{Cl}^{-}\right.$ex $]$(see text).)

\begin{tabular}{|c|c|c|c|c|c|c|c|c|c|c|c|c|c|c|c|}
\hline Station & $\begin{array}{l}\text { Distance from } \\
\text { the coast } \\
(\mathrm{km})\end{array}$ & $\mathrm{Na}^{+}$ & $\mathrm{Mg}^{2+}$ & $\mathrm{Ca}^{2+}$ & $\mathrm{NH}_{4}^{+}$ & $\mathrm{K}^{+}$ & $\mathrm{H}^{+}$ & $\mathrm{Cl}^{-}$ & $\mathrm{NO}_{3}^{-}$ & $\mathrm{SO}_{4}^{2-}$ & {[} & $\Delta C$ & $\mathrm{SO}_{\text {4ex }}^{2-}$ & $\mathrm{Cl}_{\text {ex }}^{-}$ & $\mathrm{H}^{+}$Calculated \\
\hline D10 & 4 & 10.48 & 2.39 & 0.46 & 0.15 & 0.19 & 1.14 & 12.14 & 0.32 & 1.79 & 29.10 & +0.56 & 0.52 & - & - \\
\hline D24 & 17 & 2.69 & 0.61 & 0.11 & 0.16 & 0.05 & 2.11 & 2.96 & 0.65 & 1.65 & 11.00 & +0.47 & 1.32 & - & - \\
\hline D40 & 33 & 2.65 & 0.60 & 0.12 & 0.19 & 0.04 & 0.85 & 3.10 & 0.15 & 0.63 & 8.30 & +0.57 & 0.31 & 0 & 0.46 \\
\hline D47 & 100 & 0.91 & 0.21 & - & 0.09 & - & 1.74 & 1.16 & 0.93 & 0.61 & 5.65 & +0.25 & 0.50 & 0.10 & 1.52 \\
\hline D50 & 130 & 0.96 & 0.22 & - & 0.19 & - & 1.00 & 1.09 & 0.67 & 0.54 & 4.67 & +0.07 & 0.42 & 0 & - \\
\hline D52 & 150 & 0.37 & 0.08 & - & 0.06 & - & 0.60 & 0.44 & 0.32 & 0.22 & 2.10 & +0.13 & 0.18 & 0.01 & 0.51 \\
\hline D55 & 180 & 0.32 & 0.07 & - & 0.06 & - & 1.00 & 0.42 & 0.42 & 0.39 & 2.68 & +0.22 & 0.35 & 0.05 & 0.82 \\
\hline D57 & 200 & 0.96 & 0.22 & - & 0.10 & - & 1.24 & 1.11 & 0.66 & 0.54 & 4.81 & +0.21 & 0.42 & 0 & 1.08 \\
\hline D58 & 210 & 0.57 & 0.13 & - & 0.18 & - & 1.00 & 0.69 & 0.50 & 0.36 & 3.43 & +0.33 & 0.29 & 0.02 & 0.81 \\
\hline D61 & 240 & 0.67 & 0.15 & - & 0.11 & - & 2.57 & 1.00 & 1.39 & 0.92 & 6.81 & +0.19 & 0.84 & 0.22 & 2.45 \\
\hline D64 & 270 & 0.43 & 0.10 & - & 0.05 & - & 1.05 & 0.54 & 0.42 & 0.31 & 2.90 & +0.36 & 0.26 & 0.04 & 0.72 \\
\hline D66 & 290 & 0.20 & 0.05 & - & 0.09 & - & 2.06 & 0.38 & 1.09 & 0.53 & 4.40 & +0.39 & 0.51 & 0.15 & 1.75 \\
\hline D70 & 330 & 0.60 & 0.14 & - & 0.10 & - & 1.56 & 0.76 & 0.92 & 0.48 & 4.56 & +0.24 & 0.41 & 0.06 & 1.39 \\
\hline D73 & 360 & 0.62 & 0.14 & - & 0.11 & - & 2.44 & 0.83 & 1.22 & 0.83 & 6.19 & +0.43 & 0.76 & 0.10 & 2.08 \\
\hline D77 & 400 & 0.87 & 0.20 & - & 0.15 & - & 1.27 & 1.07 & 0.72 & 0.47 & 4.75 & +0.23 & 0.37 & 0.05 & 1.14 \\
\hline D80 (1) & 430 & 0.53 & 0.12 & - & 0.12 & - & 1.60 & 0.81 & 0.95 & 0.54 & 4.67 & +0.07 & 0.48 & 0.19 & 1.62 \\
\hline D80 (2) & 430 & 0.96 & 0.22 & - & 0.07 & - & 2.20 & 1.39 & 1.31 & 0.67 & 6.82 & +0.08 & 0.55 & 0.27 & 2.13 \\
\hline
\end{tabular}


inland. It decreases, however, in most central areas. These results are discussed in relation to the glaciochemical data published for other locations on the Antarctic plateau, in particular the sulphate concentrations which depend strongly on explosive volcanic activity.

\section{INTRODUCTION}

Recent glaciochemical studies provide a better understanding - of the chemical composition of Antarctic precipitation. Most have been devoted to central Antarctic sites such as South Pole (Herron 1982, Delmas and others 1982[a], Legrand and Delmas 1984) Dome C (Delmas and others 1982[b]), Vostok (De Angelis and others 1984) and Byrd stations (Herron 1982, Palais and Legrand 1985).

It has been established that the ionic budget of recently deposited Antarctic snow is mainly contributed by sea-salt aerosol and gas-derived secondary aerosol composed of the three mineral acids $\mathrm{H}_{2} \mathrm{SO}_{4}, \mathrm{HNO}_{3}$ and $\mathrm{HCl}$. For central areas, it has been clearly demonstrated that the acid contribution dominates. In order to obtain more information about the sources of these acids, it seemed of interest to study the chemistry of snow around the central Antarctic plateau, at sites located between sea-level and $\sim 3000 \mathrm{~m}$ elevation. The traverse made in Terre Adelie during the austral summer 1982-83 from Dumont d'Urville to Dome C presented an excellent opportunity to sample recent snow layers at various locations in a relatively homogeneous geographical area. Moreover deeper firn samples were available at two sites (D 55 and D 80) in particular for investigating the influence of the major volcanic eruption of Mt Agung (in 1963) which markedly disturbed atmospheric chemistry on a global scale.

At D 57 (Zanolini and others 1985), Vostok (De Angelis and others 1984), Dome C (Delmas and others 1982[b]) and South Pole (Legrand and Delmas 1984), the same analytical procedure had been used to study the chemistry of a wide variety of snow and ice samples, so that it was possible to compare the results found in Terre Adelie to the general features of Antarctic snow chemistry.

\section{SAMPLING}

Eighteen samples of snow were collected during the 1982-83 traverse at 16 different virgin sites between Cap Prud'homme $\left(66^{\circ} 41^{\prime} \mathrm{S}, 139^{\circ} 55^{\prime} \mathrm{E}\right.$, near the sea) and D 80 $\left(70^{\circ} \mathrm{S}, 135^{\circ} \mathrm{E}\right.$, elevation $2430 \mathrm{~m}$ at $433 \mathrm{~km}$ from the coast) along the Dumont d'Urville-Vostok axis (Fig.1). The shallow layer (the top $40 \mathrm{~cm}$ ) was collected directly by pushing PTFE tubes (40 cm long) into snow upwind of the traverse track. At D 80, two samples were recovered in order to get an estimate of the natural reworking of the annual layers by wind. The time intervals integrated by this sampling (from one year near the coast to nearly three at D 55) depend on the local snow accumulation rates. Stringent precautions were taken to avoid contamination of the samples by the operators. All sampling equipment, plastic gloves and tubes had previously been cleaned several times in the laboratory with ultrapure water in a clean room and packed in sealed plastic bags. A biank value related to the sampling procedure was obtained by analyzing ultrapure water poured into PTFE tubes brought back empty to the laboratory.

At Dome C $\left(75^{\circ} \mathrm{S}, 124^{\circ} \mathrm{E}\right.$, elevation $3250 \mathrm{~m}, 1070 \mathrm{~km}$ from the coast) and D 55 (elevation $2028 \mathrm{~m}, 200 \mathrm{~km}$ from the coast) several hundred samples were collected in hand-dug snow-pits and placed in pre-cleaned disposable $30 \mathrm{ml}$ polystyrene vials (Coulter "Accuvettes") (at Dome C) or in sealed plastic bags (at D 55). The operators wore clean-room clothing, plastic gloves and masks. Only one part of these sample sets corresponding to the time period from 1959 to 1969 was used for this study. Moreover, an additional set of samples also corresponding to the same time period was obtained by re-coring a firn core recovered at D 80 in a cold room under clean-air conditions. The experimental procedure is described elsewhere (Legrand and others 1984). At Dome C, D 55 and D 80, each individual sample corresponds to about $0.1, \quad 0.1$ and 0.3 a, respectively.

\section{ANALYTICAL PROCEDURE}

All ions with the exception of $\mathrm{H}^{+}$, which was determined by acid titration (Legrand and others 1982), were measured by ion chromatography, using a Dionex apparatus, Model 10 (Legrand and others 1984). Analytical accuracy was typically from 5 to $10 \%$ (at $95 \%$ confidence
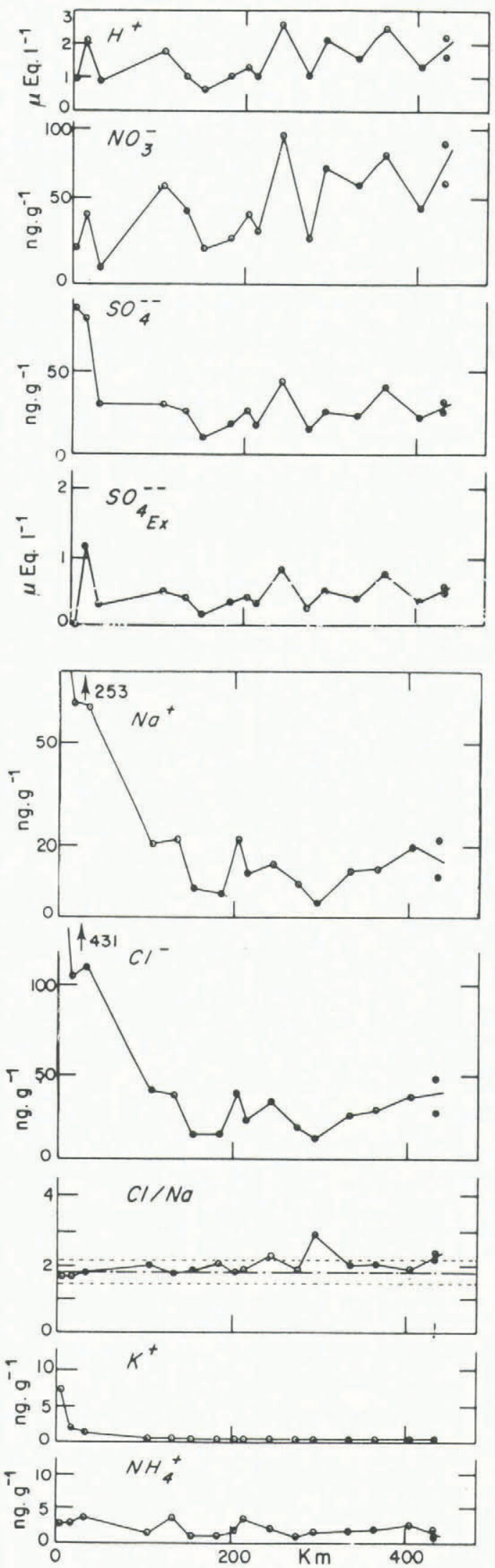

Fig.2. Ionic concentrations in surface snow along the study axis in Terre Adélie. Distances (in $\mathrm{km}$ ) are from Dumont d'Urville. Excess sulphate $\left(\mathrm{SO}_{4}^{2-} \mathrm{ex}^{2}\right)$ and the ratio $\mathrm{Cl} / \mathrm{Na}$ are calculated. The $\mathrm{Cl} / \mathrm{Na}$ ratio of sea-water (1.8) is indicated by a stippled line. 
limits). Blank values for all ions were found to be negligible with the sampling procedure used for surface samples (PTFE tubes), for the snow-pit at Dome C (Coulter Accuvettes) as well as for the re-cored firn from D 80).

On the other hand, we observed major contamination of the snow collected in the D 55 pit. This contamination, which is only significant for the acidity values, seems to be due to an organic acid contaminant. So far, the actual cause of this effect is not clearly understood (possibly the solvent of the ink in the felt pen used to mark the sample bags). Our analytical procedure also allows us to conclude that $\mathrm{F}^{-}$and $\mathrm{HCOO}^{-}$concentrations are always lower than the detection limits of 0.1 and $0.15 \mu \mathrm{eq} \mathrm{r}^{-1}$, respectively. The calculation made on the composition of the acidity (see further in text) confirms that weak organic acids, if present in Antarctic snows, are very minor impurities.

\section{DATING OF THE SNOW AND FIRN LAYERS}

Dating of the shallow snow samples is not accurate since it was only estimated from the mean value of the accumulation rates at the different sites studied. On the other hand the datings of the D 80 firn core and of the snow-pit samples were made by the method of artificial radioactivity horizons (total beta-radioactivity measurements (Pourchet and Pinglot personal communication)) and is therefore defined with an accuracy of better than 1 a, particularly around the reference horizon of January 1965 .

\section{RESULTS AND DISCUSSION}

The results of the chemical analysis of shallow snow samples are given in Table $\mathbf{I}$ and Figure 2. They show that the concentrations of the elements derived from sea salt $\left(\mathrm{Na}^{+}, \mathrm{K}^{+}\right.$and $\left.\mathrm{Cl}^{-}\right)$decrease rapidly in the first $100 \mathrm{~km}$ with the deposition of the coarsest sea-salt particles. This effect has already been described by Briat and others (1974) and by Delmas and others (1982[a]). It seems that the critical parameter for the transport of the bulk of sea-salt aerosol is elevation rather than distance from the coast, as suggested by measurements on the Ross Ice Shelf (Herron and Langway 1979). Between D 40 and D 50 elevation increases from 850 to $1730 \mathrm{~m}$. The barrier to the free penetration of sea-salt particles towards the interior probably lies between these two stations.

Such a barrier does not exist for gas-derived secondary aerosol as shown by the results of excess $\mathrm{SO}_{4}^{2-}, \mathrm{NO}_{3}^{-}, \mathrm{NH}_{4}^{+}$ and acidity. Excess $\mathrm{SO}_{4}^{2-}$ and $\mathrm{NH}_{4}^{+}$remain in the same concentration range all along the $400 \mathrm{~km}$ of the traverse whereas the nitrate content doubles from $\sim 0.5$ to $\sim 1.0$ ueq $\mathrm{r}^{-1}$ from the coast to the most interior station Acidity does not exhibit any clear trend as a function of the distance from the coast.

The sulphate values obtained in this work are significantly lower than those reported by Delmas and Boutron (1978). A possible explanation for this discrepancy, apart from the different analytical methods used in these two studies, could lie in the different time periods sampled (1981-82 and 1972-73, respectively) as well as in the representativity of the sampling itself. We have also examined the possible fractionation of sea salt $(\mathrm{NaC1})$ as a function of the distance from the coast. The $\mathrm{Cl} / \mathrm{Na}$ weight ratios are very close $(1.83 \pm 0.14)$ to the bulk sea-water ratio (1.8) along the first $200 \mathrm{~km}$ and then increase slightly (Fig. 2). This finding disagrees markedly with the previous values published by Briat and others (1974) who observed very high values of this ratio further inland (more than 13 at D $80)$. We think that these authors obtained chlorine concentrations that were much too high $\left(107 \pm 44 \mathrm{ng} \mathrm{g}^{-1}\right)$, probably because of contamination of their samples during transportation or storage. Such cases of sample contamination by gaseous chlorine compounds $\left(\mathrm{CH}_{3} \mathrm{Cl}\right.$ ?) have been reported previously by us (Legrand and others 1984).

Finally the fractionation factor of potassium with respect to its marine source is found to be close to $1(0.8)$ and the correlation between $\mathrm{Na}$ and $\mathrm{K}$ concentrations (calculated over 17 cases) is excellent $(r=0.994)$. These findings confirm that potassium has essentially a marine origin in Terre Adélie as already pointed out by Boutron (1979).

The ionic budget of snow in this geographical area was established by calculating the sum $\Sigma$ of the ionic concentrations (in $\mu$ eq $1^{-1}$ ):

$$
\begin{gathered}
\sum=\left[\mathrm{H}^{+}\right]+\left[\mathrm{Na}^{+}\right]+\left[\mathrm{NH}_{4}^{+}\right]+\left[\mathrm{K}^{+}\right]+\left[\mathrm{Mg}^{2+}\right]+\left[\mathrm{Ca}^{2+}\right]+ \\
+\left[\mathrm{Cl}^{-}\right]+\left[\mathrm{SO}_{4}^{2-}\right]+\left[\mathrm{NO}_{3}^{-}\right]
\end{gathered}
$$

$\mathrm{Mg}^{2+}$ and $\mathrm{Ca}^{2+}$ concentrations, which were measured on three of the samples only, were generally estimated from $\left[\mathrm{Na}^{+}\right]$values using the ratios of these elements in sea-water. The values of $[$ are higher than 10 at the two first stations (D 10 and D 24) only (Table I). The imbalance between cations and anions is always positive (more cations than anions) but remains slight. The highest imbalance is $12 \%$ of $\Sigma$, a result which is very satisfactory when considering the number of analyses involved in the determination of $\Sigma$.

\section{ACIDITY COMPOSITION}

As proposed by Legrand and Delmas (1984), the composition of the acidity may be investigated by calculating the sum $\left[\mathrm{SO}_{4}^{2-}\right]_{\text {exc }}+\left[\mathrm{NO}_{3}^{-}\right]+\left[\mathrm{Cl}^{-}\right]_{\text {exc }}$ and comparing the values obtained to the measured acidities $\left[\mathrm{H}^{+}\right]$. Excess sulphate and excess chloride are calculated from $\left[\mathrm{Na}^{+}\right]$:

$$
\begin{aligned}
& {\left[\mathrm{SO}_{4}^{2-}\right]_{\text {exc }}=\left[\mathrm{SO}_{4}^{2-}\right]-0.12\left[\mathrm{Na}^{+}\right]} \\
& {\left[\mathrm{Cl}^{-}\right]_{\mathrm{exc}}=\left[\mathrm{Cl}^{-}\right]-1.17\left[\mathrm{Na}^{+}\right]}
\end{aligned}
$$

Let us compare the measured (8th column of Table I) to the calculated (last column) acidity values. There is a general agreement between the average values and the variations of both parameters. This demonstrates that acidity is satisfactorily explained by the sum of the three mineral acids $\mathrm{H}_{2} \mathrm{SO}_{4}, \mathrm{HNO}_{3}$ and $\mathrm{HCl}$. The proportion of the latter $\left(\mathrm{Cl}^{-}{ }_{\text {exc }}\right)$ is, however, nearly negligible, especially in the coastal area (Table II). The percentages given in this table also show that in the last part of the traverse, acid

\begin{tabular}{|c|c|c|c|c|c|c|c|c|c|c|c|c|c|c|c|}
\hline \multirow[t]{2}{*}{ Area } & \multirow[t]{2}{*}{$\begin{array}{c}\text { Sample } \\
\text { no. }\end{array}$} & $\mathrm{Na}^{+}$ & $\mathrm{Ca}^{2+}$ & $\mathrm{Mg}^{2+}$ & $\mathrm{K}^{+}$ & $\mathrm{Cl}^{-}$ & & $\mathrm{SO}_{4}^{2-}$ & & \multirow{3}{*}{$\begin{array}{c}\mathrm{NO}_{3} \\
0.4 \\
(2 \%)\end{array}$} & \multirow{2}{*}{$\begin{array}{c}\mathrm{NH}_{4}^{+} \\
0.2 \\
(1 \%)\end{array}$} & \multirow{2}{*}{$\begin{array}{c}\mathrm{H}^{+} \\
\\
1.3 \\
(8 \%)\end{array}$} & \multirow{2}{*}{$\begin{array}{l}\mathrm{Cl}^{-} / \mathrm{Na}^{+} \\
1.76\end{array}$} & \multirow{2}{*}{$\begin{array}{r}\sum \\
16.2\end{array}$} & \multirow{2}{*}{$\begin{array}{l}\Delta c \\
0.6\end{array}$} \\
\hline & & $\begin{array}{r}5.3 \\
(33 \%)\end{array}$ & $\begin{array}{l}0.2 \\
(1 \%)\end{array}$ & $\begin{array}{l}1.3 \\
(8 \%)\end{array}$ & $\begin{array}{c}0.1 \\
(1 \%)\end{array}$ & $\begin{array}{c}6.1 \\
(38 \%)\end{array}$ & & $\begin{array}{r}1.3 \\
(8 \%)\end{array}$ & & & & & & & \\
\hline \multirow[t]{2}{*}{ A } & 3 & & & & & $\begin{array}{c}\text { Sea salt } \\
6.1 \\
(38 \%)\end{array}$ & $\begin{array}{c}\text { Excess } \\
0 \\
(0 \%)\end{array}$ & $\begin{array}{c}\text { Sea salt } \\
0.6 \\
(4 \%)\end{array}$ & $\begin{array}{c}\text { Excess } \\
0.7 \\
(4 \%)\end{array}$ & & & & & & \\
\hline & & $\begin{array}{r}0.6 \\
(14 \%)\end{array}$ & - & $\begin{array}{l}0.15 \\
(3 \%)\end{array}$ & - & $\begin{array}{c}0.8 \\
(18 \%)\end{array}$ & & $\begin{array}{c}0.5 \\
(12 \%)\end{array}$ & & $\begin{array}{c}0.8 \\
(18 \%)\end{array}$ & $\begin{array}{l}0.1 \\
(2 \%)\end{array}$ & $\begin{array}{c}1.5 \\
(33 \%)\end{array}$ & 2.07 & 4.6 & 0.2 \\
\hline B & 14 & & & & & $\begin{array}{c}\text { Sea salt } \\
0.7 \\
(16 \%)\end{array}$ & $\begin{array}{c}\text { Excess } \\
0.1 \\
(2 \%)\end{array}$ & $\begin{array}{c}\text { Sea salt } \\
0.1 \\
(2 \%)\end{array}$ & $\begin{array}{c}\text { Excess } \\
0.4 \\
(10 \%)\end{array}$ & & & & & & \\
\hline
\end{tabular}

TABLE II. CHEMICAL COMPOSITION OF SNOW IN COASTAL AREAS (A) AND BETWEEN 30 AND $430 \mathrm{~km}$ FROM THE SEA (B). (Average concentrations $\left[\right.$ and $\mathrm{C}$ (see Table I) are in $\mu \mathrm{eql}^{-1}$. Ionic distribution is in $\%$ of ionic budget.) 


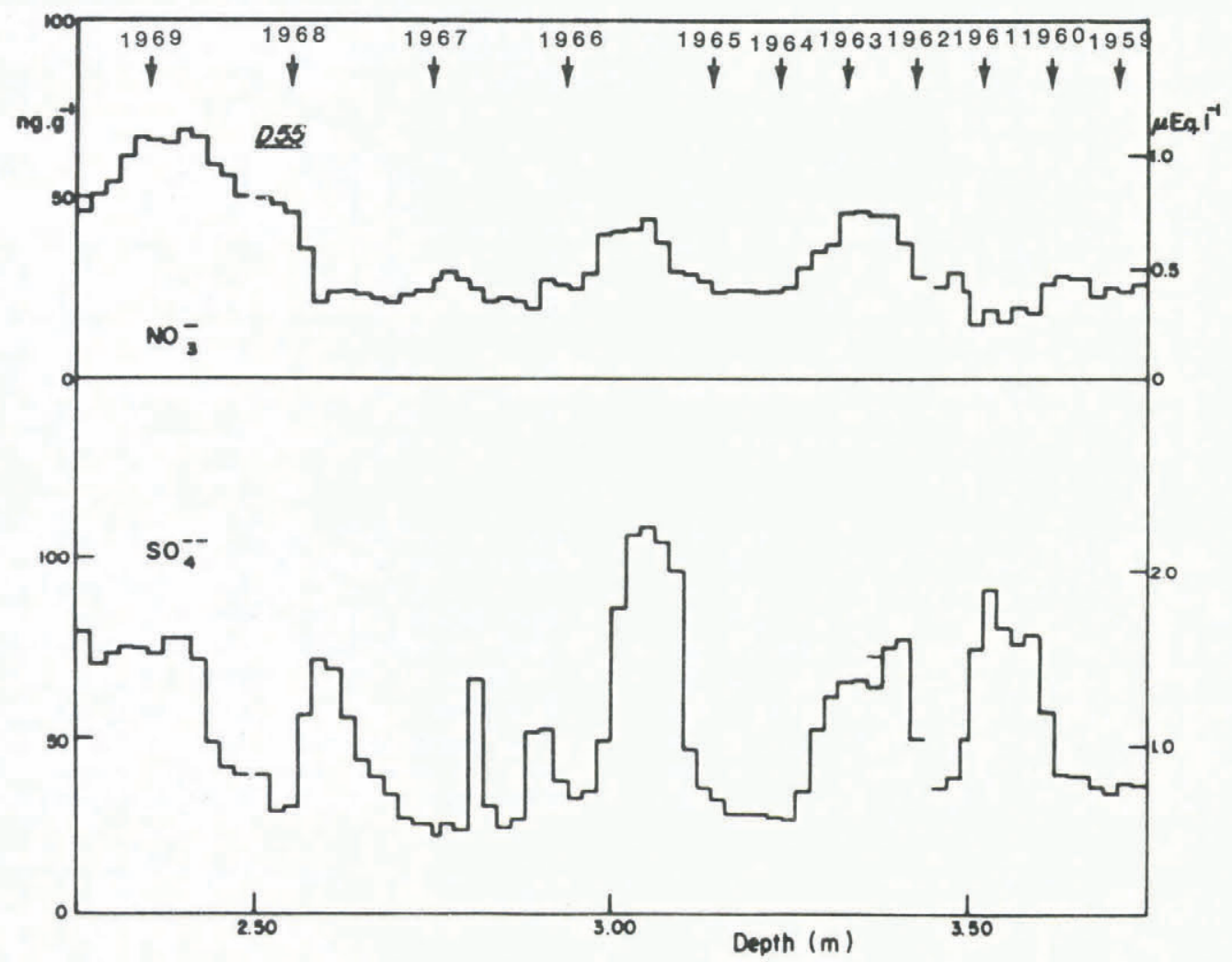

Fig.3. Station D 55. Concentration profiles (in $\mathrm{ng} \mathrm{g}^{-1}$ and $\mu \mathrm{eq} 1^{-1}$ ) of sulphate and nitrate in a snow-pit from 2 to $4 \mathrm{~m}$ depth (time period from 1959 to 1969).

contributions amount to about $2 / 3$ of the total ionic budget, $\mathrm{HNO}_{3}$ being the major ionic trace element present in snow.

Finally, it must be noted that $\mathrm{NH}_{4}^{+}$concentrations are found to be very low and stable all along the traverse. This observation shows that the degree of neutralization of the acidity is low (as already found at other Antarctic locations), and also that the Southern Ocean is not a source of ammonia, a conclusion which is in agreement with most works on the origin of this gas in the troposphere.

Table III summarizes the results obtained for the time period from 1959 to 1969 at D 55, D 80, Dome C and South Pole. In the same table we have also reported a few physical parameters of interest in order to obtain a better understanding of the composition of the origin of the acidity $\left(\mathrm{H}_{2} \mathrm{SO}_{4}, \mathrm{HNO}_{3}\right.$ and $\left.\mathrm{HCl}\right)$ in Antarctica. First of all, it must be noted that no clear relationship can be found between the contents of these acids and elevation of snow accumulation rate such as those proposed by Herron (1982) for the nitrate and excess sulphate content of polar snows. Marked differences are observed in the composition of the snow acidity at these four sites. The importance of hydrochloric acid is negligible at D 55, as was observed in coastal areas, whereas it represents nearly one third of the acidity at Dome C. This acid is also particularly important at D 80 and at South Pole. Its formation is assumed to follow the reaction:

$$
\mathrm{H}_{2} \mathrm{SO}_{4}+\underset{\text { (sea salt })}{2 \mathrm{NaCl}} \rightarrow 2 \mathrm{Na}_{2} \mathrm{SO}_{4}+2 \mathrm{HCl}
$$

at the border of the continent or in the first $100 \mathrm{~km}$ where sea-salt aerosol is abundant and where we observed $\mathrm{Cl} / \mathrm{Na}$ ratios lower than the marine ratio (Table II). In this case $\mathrm{HCl}$ would be transported inland and deposited preferentially on the Antarctic plateau.

Nitrate concentrations vary in the range from 0.3 to $1.14 \mu \mathrm{eq} \mathrm{I}^{-1}$ at D 55 and from 0.5 to $1.7 \mu \mathrm{eq} \mathrm{r}^{-1}$ at D 80 . This is also the range observed in the D 57 ice core except for some exceptionally high values (Zanolini and others 1985). It represents from 35 to $50 \%$ of the acidity during the study period, except at Dome C where its level is

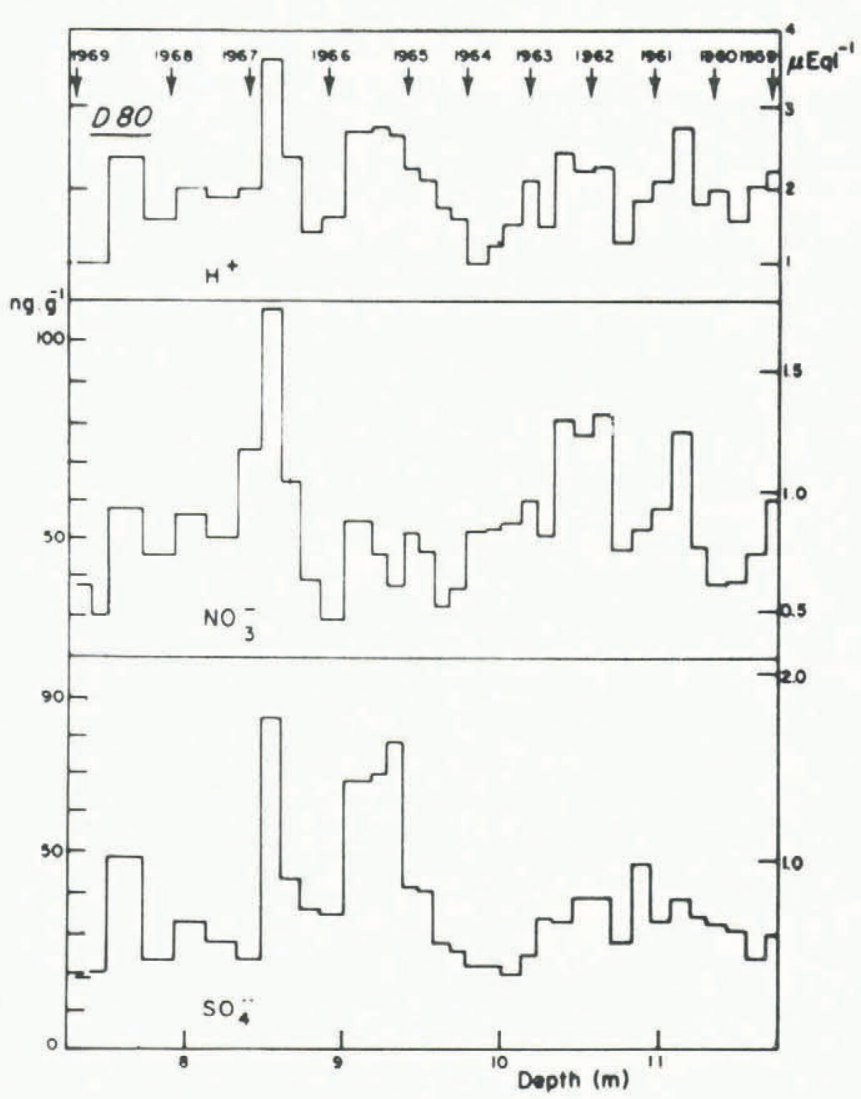

Fig.4. Station D 80. Concentrations (in $\mathrm{ng} \mathrm{g}^{-1}$ and $\mu \mathrm{eq} \mathrm{I}^{-1}$ ) of $\mathrm{H}^{+}, \mathrm{NO}_{3}^{-}$and $\mathrm{SO}_{4}^{2-}$ in firn from 7 to $12 \mathrm{~m}$ depth (time period from 1959 to 1569 ). 
TABLE III. MEAN COMPOSITION OF THE ACIDITY AT FOUR ANTARCTIC LOCATIONS DURING THE SAME TIME PERIOD FROM 1959 TO 1969. (Accumulation rates are (1) from M Pourchet (private communication) and (2) from Jouzel and others (1983).)

\begin{tabular}{|c|c|c|c|c|c|c|c|c|c|}
\hline $\begin{array}{l}\text { Sampling } \\
\text { station }\end{array}$ & $\begin{array}{l}\text { Distance from } \\
\text { the coast } \\
(\mathrm{km})\end{array}$ & $\begin{array}{l}\text { Elevation } \\
\text { (m) }\end{array}$ & $\begin{array}{l}\text { Accumulation } \\
\text { rate } \\
\left(\mathrm{g} \mathrm{cm}^{-2} \mathrm{a}^{-1}\right)\end{array}$ & $\begin{array}{c}\mathrm{H}^{+} \\
\text {(ueq } \mathrm{I}^{-1} \text { ) }\end{array}$ & $\begin{array}{l}\text { Excess } \\
\text { chloride } \\
\left(\mu \mathrm{eq} \mathrm{I}^{-1}\right)\end{array}$ & 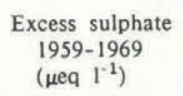 & $\begin{array}{c}\text { Excess sulphate } \\
\text { 1959-1964 } \\
\left(\mu \text { eq } 1^{-1}\right)\end{array}$ & $\begin{array}{c}\mathrm{NO}_{3}^{-} \\
\left(\mu \text { eq } \mathrm{I}^{-1} \text { ) }\right.\end{array}$ & $\begin{array}{c}\text { Sample } \\
\text { no. }\end{array}$ \\
\hline DSs & 180 & 2028 & $8.3(1)$ & 1.53 & $\begin{array}{c}0 \\
(0 \%)\end{array}$ & $\begin{array}{c}1.00 \\
(65 \%)\end{array}$ & 1.00 & $\begin{array}{c}0.53 \\
(35 \%)\end{array}$ & 67 \\
\hline D80 & 430 & 2525 & 23.0 (1) & 1.97 & $\begin{array}{l}0.18 \\
(10 \%)\end{array}$ & $\begin{array}{c}0.71 \\
(40 \%)\end{array}$ & 0.60 & $\begin{array}{l}0.87 \\
(50 \%)\end{array}$ & 35 \\
\hline Dome $\mathrm{C}$ & 1070 & 3240 & $3.6(1)$ & 2.60 & $\begin{array}{l}0.83 \\
(30 \%)\end{array}$ & $\begin{array}{c}1.80 \\
(64 \%)\end{array}$ & 1.36 & $\begin{array}{l}0.17 \\
(6 \%)\end{array}$ & 82 \\
\hline Scuth Pole & 1274 & 2880 & $8.3(2)$ & 3.4 & $\begin{array}{l}0.52 \\
(15 \%)\end{array}$ & $\begin{array}{c}1.40 \\
(42 \%)\end{array}$ & 0.92 & $\begin{array}{c}1.44 \\
(43 \%)\end{array}$ & 92 \\
\hline
\end{tabular}

exceptionally low $\left(0.17 \mu\right.$ eq $\mathrm{r}^{-1}$, which is $6 \%$ of acidity). The maximum values of the nitrate profiles at D 55 (Fig.3) and D 80 (Fig.4) are not found in the same years at both stations: the highest levels in 1968-69 at D 55 are not observed at D 80 . Conversely the relatively low values from 1955 to 1965 at D 80 do not appear in the D 55 profile. Therefore the deposition patterns of $\mathrm{HNO}_{3}$ in this area appear to be quite different at distances of only $250 \mathrm{~km}$ with an elevation difference of $500 \mathrm{~m}$. Finally, even with sufficient sampling (upper part of the D 55 pit) no clear, seasonal variations such as those found at South Pole (Legrand and Delmas 1984) are visible.

The case of sulphuric acid is different as its concentration in snow depends on the chronology of large volcanic events (Delmas and Boutron 1980). In the absence of eruptions (for instance during the period from 1959-1964), (Table III) the spatial distribution of $\mathrm{H}_{2} \mathrm{SO}_{4}$ fallout seems to exhibit less variability than the other two acids as already discussed by Delmas (1982). The two extreme mean values of $\mathrm{H}_{2} \mathrm{SO}_{4}$ (at D 80 and Dome C) have

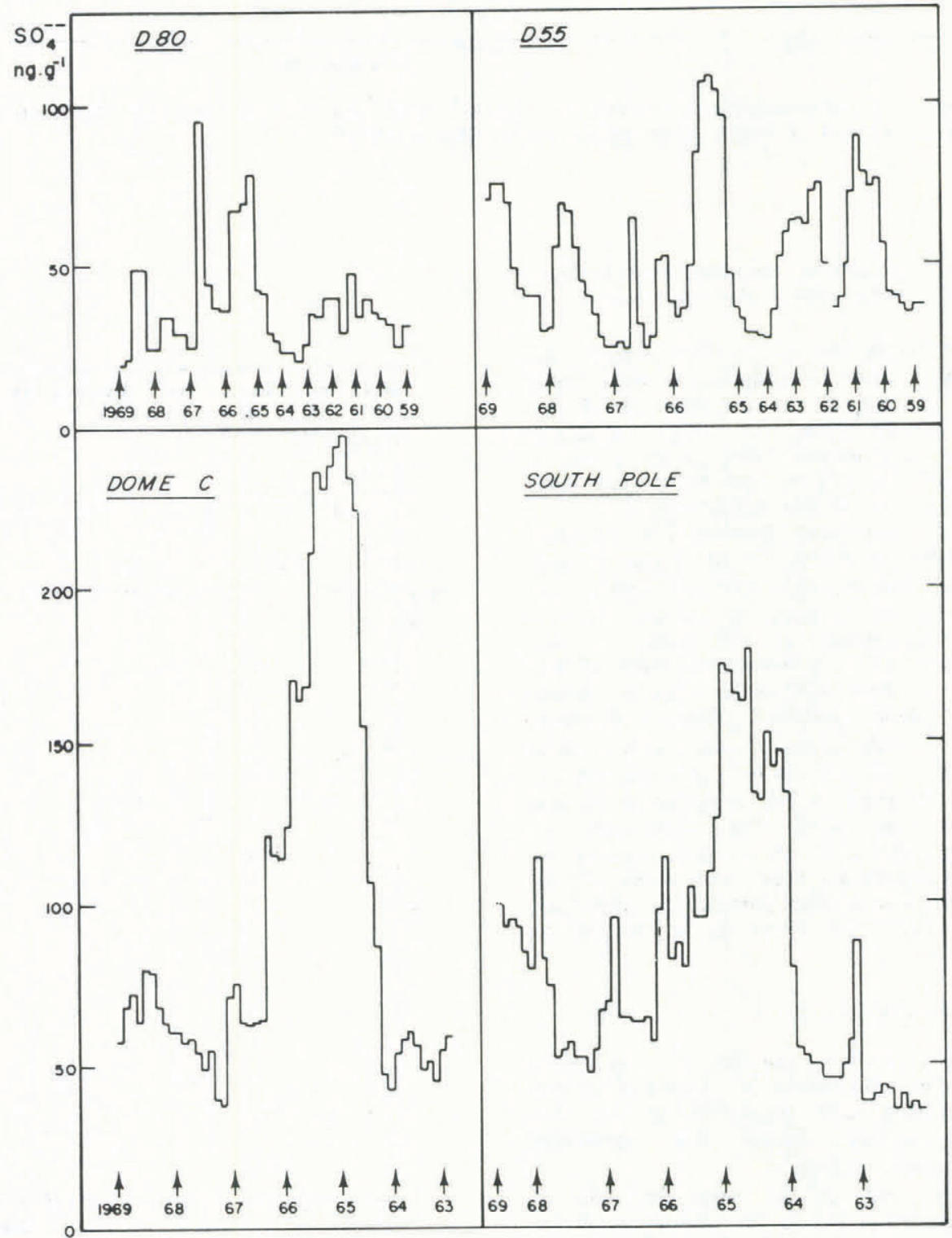

Fig.5. The Agung signal (in 1965-66) at four Antarctic locations (D 80, D 55, Dome C and South Pole). Note that the sulphate concentration scale (in $\mathrm{ng} \mathrm{g}^{-1}$ ) is identical for all stations. 
a ratio of only 2.2 whereas those of $\mathrm{HNO}_{3}$ and $\mathrm{HCl}$ have a ratio of 8.4 and $\sim \infty$ respectively.

The imprint of the Agung eruption is well marked in the years 1965-66 (Figs.3 and 4). The fluctuations of the sulphate background are in the range from 0.5 to 3.0 and from 0.6 to $1.7 \mu \mathrm{eq}$ at $\mathrm{D} 80$ and $\mathrm{D} 55$ respectively, whereas the highest sulphate values after Agung are 1.8 and 2.2 , indicating that the Agung signal is better defined at D 80 than at D 55 where it lasted apparently only one year (1965). In fact the impact of this eruption on the sulphate profiles of Antarctic snow is much more pronounced in central regions such as Dome $\mathrm{C}$ or S.Juth Pole (Fig.5). At these two stations the sulphate increase starts at the beginning of 1964 , i.e. apparently one year before $D 55$ and D 80. However, it may be argued that this time-iag of one year probably reflects the detectability of Agung's fallout over the general sulphate background rather than a different time of first arrival of the volcanic products at these sites.

Identical scales were chosen for the sulphate concentrations in the four profiles of Figure 5 in order to show that the height of the volcanic signal follows the order Dome C > South Pole > D $80>$ D 55. It appears that this order is approximately that of the snow accumulation rates at the four stations, with the exception of D 55 and South Pole, which have nearly the same accumulations $\left(8.3 \mathrm{~g} \mathrm{~cm}^{2} \mathrm{a}^{-1}\right)$ and do not present identical responses to volcanic fallout (Table III). It may be assumed that geographical considerations should probably also be taken into account in evaluating the impact of a volcanic eruption on Antarctic snow chemistry (Delmas and others in press).

\section{CONCLUSION - SOURCES OF ACIDS}

The spatial and temporal variations reported in this paper provide information on the most important parameters capable of a marked influence on the composition of acids in Antarctic snow.

(1) The influence of remoteness from marine surfaces is only appreciable for $\mathrm{HCl}$.

(2) Equation (4) probably illustrates the formation of particulate $\mathrm{Na}_{2} \mathrm{SO}_{4}$, which is deposited rapidly, and of gaseous $\mathrm{HCl}$, which is allowed to travel further inland.

(3) The fact that no clear spatial trend appears in the $\mathrm{H}_{2} \mathrm{SO}_{4}$ content of snow does not signify that this acid ("excess-sulphate") is not of marine origin. This in fact signifies that the life-time of $\mathrm{H}_{2} \mathrm{SO}_{4}$ in the Antarctic troposphere is sufficiently long to allow a nearly even deposition pattern over the study area.

(4) No effect could be detected on $\mathrm{HNO}_{3}$ or $\mathrm{HCl}$ profiles after the eruption of Agung, the impact being limited to the concentrations of sulphate. This was also verified for the eruptions of Tambora (1815) and Galunggung (1822) (Zanolini and others 1985). The sulphate profiles are disturbed generally for 2 a after the eruption year and more significantly in low accumulation areas of central Antarctica than in coastal regions.

(5) Nitrogen compounds ( $\mathrm{NH}_{4}^{+}$and $\mathrm{NO}_{3}^{-}$) apparently have no marine source as is also generally accepted at mid-latitudes.

(6) Nitric acid profiles exhibit relatively large spatial and temporal variations. These variations are not sufficiently typical to indicate one $\mathrm{HNO}_{3}$ source rather than another. It has been calculated that an important source of atmospheric $\mathrm{HNO}_{3}$ seems to be located in the upper troposphere in the tropics (lightning) (Kley 1983). Long-range transport of this acid to the south polar regions with a subsequent fallout at mid-altitude sites in Antarctica $(2000-3000 \mathrm{~m})$ is one possibility. Formation of this acid in the Antarctic troposphere (perhaps by aurorae) cannot be ruled out. Nevertheless our results demonstrate clearly that this acid can sometimes be dominant in the acidity composition of Antarctic snow.

\section{ACKNOWLEGEMENTS}

We are indebted to $\mathrm{M}$ Pourchet for sample collection. This research was financed by Terres Australes et Antarctiques Françaises (TAAF) and Centre National de la Recherche Scientifique Programme Interdisciplinaire de Recherche sur l'Environnement (CNRS-PIREN).

\section{REFERENCES}

Boutron C 1979 Alkali and alkaline earth enrichments in aerosols deposited in Antarctic snows. Atmospheric Environment 13 (7): 919-924

Briat M, Boutron C, Lorius C 1974 Chlorine and sodium content of East Antarctica firn samples. Journal de Recherches Atmosphériques 8: 895-901

De Angelis M, Legrand M, Petit J R, Barkov N I, Korotkevich Ye S, Kotlyakov V M 1984 Soluble and insoluble impurities along the $950 \mathrm{~m}$ deep Vostok ice core (Antarctica) - climatic implications. Journal of Atmospheric Chemistry 1: 215-239

Delmas R J 1982 Antarctic sulphate budget Nature 299(5885): 677-678

Delmas R J, Boutron C 1978 Sulfate in Antarctic snow: spatio-temporal distribution. Atmospheric Environment 12 (1-3): $723-728$

Delmas R J, Boutron C 1980 Are the past variations of the stratospheric sulfate burden recorded in central Antarctic snow and ice layers? Journal of Geophysical Research 85 (C10): 5645-5649

Delmas R J, Briat M, Legrand M 1982[a] Chemistry of south polar snow. Journal of Geophysical Research 87 (C6): 4314-4318

Delmas R J, Barnola J M, Legrand M 1982[b] Gas-derived aerosol in central Antarctic snow and ice: the case of sulphuric and nitric acids. Annals of Glaciology 3 71-76

Delmas $\mathrm{R} \mathrm{J}$, Legrand $\mathrm{M}$, Zanolini $\mathrm{F}$, Aristarain $\mathrm{A} \mathrm{J}$ In press. Volcanic deposits in Antarctic snow and ice. Journal of Geophysical Research

Herron M M 1982 Impurity sources of $\mathrm{F}^{-}, \mathrm{Cl}^{-}, \mathrm{NO}_{3}{ }^{-}$and $\mathrm{SO}_{4}{ }^{2-}$ in Greenland and Antarctic precipitation. Journal of Geophysical Research 87 (C4): 3052-3060

Herron M M, Langway C C Jr 1979 Dating of Ross Ice Shelf cores by chemical analysis. Journal of Glaciology 24 (90): 345-357

Jouzel J, Merlivat L, Petit J R, Lorius C 1983 Climatic information over the last century deduced from a detailed isotopic record in the south polar snow. Journal of Geophysical Research 88 (C4): 2693-2703

Kley D 1983 The budget of tropospheric nitrate in remote oceanic regions. Paper presented at the 5th CACGP International Conference, Oxford, 28/08-4/09

Legrand M, Delmas R J 1984 The ionic balance of Antarctic snow: a 10-year detailed record. Atmospheric Environment 18 (9): 1867-1874

Legrand M, Aristarain A J, Delmas R J 1982 Acid titration of polar snow. Analytical Chemistry 54 (8): 1336-1339

Legrand M, De Angelis M, Delmas R J 1984 Ion chromatographic determination of common ions at ultratrace levels in Antarctic snow and ice. Analytica Chimica Acta 156: 181-192

Palais J M, Legrand M 1985 Soluble impurities in the Byrd station ice core, Antarctica: their origin and sources. Journal of Geophysical Research 90(C1): 1143-1154

Zanolini F, Delmas R J, Legrand M 1985 Sulphuric and nitric acid concentrations and spikes along a $200 \mathrm{~m}$ deep ice core at D 57 (Terre Adélie, Antarctica). Annals of Glaciology 7: 70-75 